\title{
Between anarchism and communism Independent Socialists and the attempt for a fourth power in the Bohemian left in 1923-1925
}

\section{STANISLAV HOLUBEC}

Department of Social Science, Faculty of Education, University of South Bohemia in České Budějovice, České Budějovice, The Czech Republic e-mail: sholubec@pf.jcu.cz

\begin{abstract}
The presented study first summarises the development of Czech anarchism (independent socialism), or its nationally orientated part before World War I and its becoming mainstream in Czech politics between 1914 and 1918 culminating in a merger with national social party. It further describes the marginalisation of this stream in Bohemian politics in 1918-1923 given the calming of the post-war situation and the radicalisation of this group, which culminated in its exclusion from the ranks of the Socialist Party. The main theme of the text is an analysis of the attempt by this group to build its own party entity in 1923-1925. In looking for the cause of the failure of this attempt, I argue that the Czechoslovak political landscape was stabilised, which made it difficult for new parties to form, even though they could rely on several nationally known personalities and several thousand activists. As a result of the radical left-wing orientation of the Independent Socialists, they did not aim for social democracy after realizing their failure, but for the ranks of the Communist Party of Czechoslovakia (KSČ), which was close to it mainly because of the Czech anarchists' admiration for the Bolshevik revolution. In conclusion, I argue that the people representing this stream did not have much success in the Communist Party, because they differed from the members of this party in their rather middle-class habitus and, as former members of the Socialist Party, they had biographies that were suspicious for the KSČ and they did not gain much respect as it was a group that had been unsuccessful in previous years and was quite small compared to the membership base of the KSČ. The failure of the Czech Independent Socialists does not deviate from European trends, where the political groups between the Social Democrats and the Communists did not gain a foothold even in other countries in the 1920s and 1930s, because the dilemma of "going with Moscow" or remaining on the platform of parliamentary democracy did not allow for compromise. ${ }^{1}$
\end{abstract}

\section{Keywords:}

Communist Party of Czechoslovakia (KSČ), Independent Socialists, Bohuslav Vrbenský, Luisa Landová-Štychová

1 This study is the result of an institutional research of Faculty of Education, University of South Bohemia in České Budějovice. 


\section{Introduction}

The story of the Vrbenský group, which tried to build a fourth force in 1923-1925 within the Czech Left (along with the Communists, Social Democrats and National Socialists), is the story of a political movement called anarchism, or its specific Bohemian offshoot, which we could call national-anarchist. The following text broaches the question of the roots of this attempt, especially the separation of the anarchist stream from the Socialist Party in 1923. It further deals with the reasons for the failure of this attempt and the reasons the group decided to join the Communist Party of Czechoslovakia in 1925. The literature devoted to this stream is quite extensive, but it deals mainly with the existence of anarchists before the First World War, and in addition historiography from the period before 1989 was too critical of the anarchist stream and viewed it somewhat ahistorically as a direction destined a priori to failure, although it was somewhat rehabilitated in their eyes that most anarchists went to the Communist Party after $1921 .^{2}$

The story of the Bohemian anarchists or anarcho-communists begins in the decades before the First World War, when an anarchist movement was formed in European countries to the left of social democracy, which pursued several goals: above all, it wanted to be more radical than social democratic parties. While the party was already pursuing its goals at the time through unions, elections, interest groups, or strikes, anarchists preferred strikes and agitations and did not mind or use violence. Second, the anarchists did not focus only on the destruction of capitalism, but they also perceived the church and the state represented by the army and police as equal enemies.

A Czech specific feature was that the anarchists oriented more nationalistically than social democracy did. The reason can be seen in the fact that the radical ideas of anarchism found a response mainly in the most difficult or worst paid branches of labour, in mining and textiles, which were located largely on the Czech-German ethnic border, in northern and eastern Bohemia. Thus, for anarchists, social oppression was always combined with national oppression, and they saw social democracy as a movement that was far too international. According to the

2 Eg., KOUKAL, Pavel: Václav Draxl. Masarykova demokratická akademie, Ústí nad Labem 2010; MAREK, Pavel: Čeští anarchokomunisté (Czech anarcho-communists). In: MALÍŘ, Jiří - MAREK, Pavel a kol.: Politické strany. Vývoj politických stran a hnutí v českých zemích a Československu v letech 1861-2004, 1. díl (Období 1861-1938) (Political Parties. The development of political parties and movements in the Czech lands and Czechoslovakia in 1861-2004, Vol. 1 /1861-1938/). Doplněk, Brno 2005, pp. 747-762. Idem: Český anarchismus (Czech anarchists). In: Ibid., pp. 241-254.; TOMEK, Václav: Český anarchismus 1890-1925 (Czech Anarchism, 1890-1925). Filosofia, Praha 1996; TOMEK, Václav - SLAČÁLEK, Ondřej: Anarchismus. Svoboda proti moci. (Anarchism. Freedom against power). Vyšehrad, Praha 2006; TŮMA, Jiř́i: Bohuslav Vrbenský. O životě a díle revolucionáře (Bohuslav Vrbenský. The life and work of a revolutionary). Severočeské nakladatelství, Ústí nad Labem 1980; WOHLGEMUTHOVÁ, Renata: Př́spěvek $k$ dějinám českého anarchistického hnutí v letech 1900-1914 (A contribution on the history of the Czech anarchistic movement in 1900-1914). Academia, Praha 1971. 
anarchists, Marxism was a German teaching, and they preferred French (Proudhon), or Russian (Bakunin, Kropotkin) Socialism. ${ }^{3}$ Unlike social democracy, Czech anarchism was also a relatively socially polarized movement: it consisted mainly of North Bohemian miners, East Bohemian textile workers and, in addition, groups of Prague students and artists. Despite several thousand supporters in northeast Bohemia and a good position in the local unions, the anarchists could not become a major force in the Czech political camp. Whereas social democracy began to grow rapidly after 1900 and gained importance in its struggle for universal suffrage, the anarchists did not experience a similar rise with their contempt for elections and stagnated in the last decade before the First World War. ${ }^{4}$

Sometime after 1908, a new generation of leaders began to assert themselves in it, such as Bohuslav Vrbenský ${ }^{5}$ or Vlastimil Borek ${ }^{6}$, who wanted to imitate the success of social democracy. One way was to try to transform the anarchists into a political party, which the movement tried in the spring of 1914, but with only half the success. The formation of the party was accompanied by quarrels and the result was a compromise that the new entity should not be called a party or participate in national elections. ${ }^{7}$ The indecisiveness of the anarchist manifesto was also evident in the question of what social establishment they were striving for. Although they were against the monarchy, they did not want to replace it with some anarchist communes, but in principle a state unit on the territory of ethnically Czech (i.e., without the German-speaking parts of Bohemia and Moravia) and ethnically Slovak territory. The whole of Europe was to be transformed into similar national units, and even the diasporas were to return to these units (e.g., the Viennese Czechs). ${ }^{8}$ What is particularly remarkable about the whole organization is that

3 For more detail, see SLAČÁLEK, Ondřej: Socialismus činu proti „vlažnému blátu“. Bývalí anarchisté, Svaz komunistických skupin a založení komunistické strany (Socialism an act against "lukewarm mud". Former anarchists, the Union of Communist Groups and the founding of the Communist Party). Pamět a dějiny, 2021, Vol. 15, No. 2, pp. 20-33.

4 MĚCHÝŘ, Jan: Bouřlivý kraj (Roaring land). Severočeské nakladatelství, Ústí nad Labem 1983, p. 269.

5 The physician and politician Bohuslav Vrbenský (29. 3. 1882 - 25. 11. 1944) was during his university studies an activist of the student associations, later anarchist organisations. He was interned during the First World War. In 1919, along with other anarchists, he joined the National Social Party, renamed the Socialist Party, and after the establishment of Czechoslovakia, he held ministerial posts several times. In 1923 he left the Socialist Party and after an unsuccessful attempt to establish his own Party of Independent Socialists he joined the Communist Party of Czechoslovakia. He then served as chairman of the Society of Friends of the USSR and in 1938 he was elected deputy mayor of Prague. After the Nazi occupation of the Czech lands, he went to the USSR.

6 The journalist and politician Vlastimil Borek (23. 12. 1886 - 21. 12. 1952) graduated from the mechanical engineering department of the Czech Technical University and before the First World War he was an anarchist activist. He was imprisoned during the war, and after 1918 he was a leading press journalist for the Socialist Party. Along with Bohuslav Vrbenský, he founded the Party of Independent Socialists and in 1925 he joined the Communist Party. He then worked as a leading communist journalist, after 1939 he left for the Soviet Union. He returned to his homeland after the liberation in 1945 and held senior positions at the Ministry of Foreign Affairs, from 1949 to 1952 he was Deputy Minister.

7 TOMEK, Václav: Český anarchismus 1890-1925, p. 73.

8 WOHLGEMUTHOVÁ, Renata: Př́spěvek k dějinám českého anarchistického hnutí v letech 1900-1914, p. 67. 
the new entity was called the Federation of Anarchist-Communists, which was the first use of the communist adjective in the name of an organization active in Czech politics. This name probably led many anarchists after 1917 to sympathize with the Bolsheviks, who shortly after the October Revolution decided to abandon the name of social democracy, discredited by the party's vote for the war in 1914, revert to Marx's long-standing name of communists.

The second path that some anarchists tried shortly before 1914 was to get closer to existing political parties. National social party which was very reluctant to expropriate capital were out of the question, even though the party's youth wing was close to the anarchists in their anti-militarist activities. So, there were the social democrats. Anarchist leaders tried to get closer to this party in 1913 with the help of a newly formed atheists movement (Union of Socialistic Monists), ${ }^{9}$ but the social democrats rejected this reproachment, ${ }^{10}$ because a party of hundreds of thousands members that did not want to ally with several thousand radicals and did not want to alienate its religious minded voters. ${ }^{11}$

The First World War put the anarchists in a completely different situation. Unlike the Social Democrats who adopted a loyal stance to the state, the authorities immediately began to persecute them and their leaders were sent into internment. ${ }^{12}$ Here they found themselves along with the national social activists as well as with the representatives of the anti-clerical movement Free Thought ${ }^{13}$, which before the war was another radical current of Czech politics. ${ }^{14}$ In this internment, a post-war alliance of these forces began to emerge. The second significant change was the general radicalization of political life, which began to bring the hitherto marginal anarchist current closer to the mainstream of Bohemian politics. Suddenly, the

9 On the Federation of Socialist Monists, see also OVČÁČKOVÁ, Lenka: Die Rezeption des naturwissenschaftlichen Monismus von Ernst Haeckel im tschechischen Kulturraum. In: MATIS, Herbert - REITER, Wolfgang L. (eds.): Darwin in Zentraleuropa. Die wissenschaftliche, weltanschauliche und populäre Rezeption im 19. und frühen 20. Jahrhundert. Lit Verlag, Wien 2018, pp. 311-341.

10 Mimořádná valná hromada svazu (Extraordinary General Assembly of the Union). Plameny, 1913, Vol. 6, No. 7, unpaginated.

11 FASORA, Lukáš: Stáří $k$ poradě, mládí k boji. Radikalizace mladé generace českých socialistů 19001920 (The Old to Order, the Young to Battle. Radicalisation of the young generation of Czech socialists, 1900-1920). CDK, Brno 2015, p. 83.

12 TŮMA, Jiří: Bohuslav Vrbenský, p. 31.

13 Free Thought originated in 1904 as the Czech section of the International Union of Free Thinkers, founded in 1880. Through its activities, it focused on the fight against the Catholic Church and religion in general. It was banned during the First World War. After 1918, it campaigned for the enactment of the possibility of being without religion and for the separation of church and state. After the Communist wing broke away from it, it was close to the National Socialist Party. During the Nazi occupation, it was dissolved and after the liberation in 1945 it merged with other atheist organizations into the Union of Citizens without Religion.

14 Národní archiv České republiky (National Archive of the Czech Republic, hereinafter only NA), f. (Fund) Landová-Štychová Luisa (hereinafter only 1017), k. (Box) 5, Landová-Štychová Luisa: Kolem 14. řijna 1918. Předneseno v Klubu mladých na Žižkově (Around 14 October 1918. Presented the Club of the Youth in Žižkov), manuscript, 14. 10. 1937, p. 12. 
demands of the anarchists to destroy the monarchy, establish national independence, and eliminate capitalism did not sound as radical as they had before the war.

The third impulse for the anarchists was the response to the Bolshevik revolution, which in part of Czech society rehabilitated the idea of the feasibility and legitimacy of a radical social transformation, which had no longer been widely expected by social democrats in the pre-war decades. Moreover, the Czech anarchists did not identify with parliamentarism and elections, so they easily accepted the dissolution of parliament and thus the end of democracy in Russia in February 1918, after which the moderate Social Democrats stopped sympathizing with the Bolsheviks. ${ }^{15}$ On the contrary, anarchists did not stop sympathizing with the Bolsheviks, even after they began repressing Russian anarchists.

Even before the First World War, the National Social party wanted to become the main leftist power of Czech politics and also somewhat radicalised. Whereas previously they had considered the anarchists to be too radical movement, around 1917 they began to appear to them as a promising ally in their plan. The demands of the anarchists now sounded very convincing to them, and the anarchist leaders were also crowned with the halo of the prisoners of the Austrian dungeons. On the contrary, the anarchists called for a connection with both the National Socials and the Social Democrats, and in this "union" they perceived themselves to be a kind of "keystone". While the Social Democrats were reluctant to join the project, talks between the leaders of the anarchists and national socials began in early 1918, which resulted in the anarchists movement joining the party in April of that year, along with social-liberal groups (some members of the so-called Realistic party, the Czech Democracy group around the philosopher František Krejči). ${ }^{16}$ In reflection on this, the party then chose a new name, the Czech (later Czechoslovak) Socialist party, and adapted its manifesto to the anti-capitalist views of the anarchists. Those in the new party were given a very strong representation in the presidency (approximately one-fifth of the seats), even though no more than a few thousands of anarchists joined the national socials and they made only a few percent of the current membership base. ${ }^{17}$ Although the anarchist representatives were not seated in the highest body of Czech political camp, Czechoslovak National Committee, established in July 1918, where the Socialist Party had only four seats, they were sent to the emerging Czechoslovak National Assembly (parliament) in November of the same year (Vrbenský, Landová-Štychová, S. K. Neumann ${ }^{18}$ ) and acquired a ministerial seat (Vrbensky).

15 FASORA, Lukáš: Stář́ k poradě, mládí k boji, p. 186.

16 KÁRNíK, Zdeněk: Socialisté na rozcestí. Habsburk, Masaryk či Šmeral? (Socialists at a Crossroads. Habsburg, Masaryk or Šmeral?) Svoboda, Praha 1968, p. 227.

17 NA, f. 1017, k. 139, Statistika o stavu místních politických organizací Československé strany socialistické 1. 1. 1921 (Statistics on the state of the local political organisations of the Czechoslovak Socialist Party as of 1 January 1921), unpaginated.

18 Stanislav Kostka Neumann (5. 6. 1875 - 28. 6. 1947), journalist and poet. He did not finish his secondary education and before World War I established himself as a successful author, translator 


\section{Vrbenský's group in the new republic}

However, soon, already from January 1919, the anarchists began to build on the most radical pole of Czechoslovak politics. ${ }^{19}$ In the government as the Minister of Supply, Vrbenský gained the reputation as a person who was willing to put the republic in debt within improving the supply of foodstuffs to the poorest. ${ }^{20}$ Although the anarchists dissolved their Federation of Bohemian Anarchists-Communists, ${ }^{21}$ Stanislav Kostka Neuman issued the magazine Červen, which built on the pre-war anarchist magazines and continued to be a platform of the de facto existing movement. Moreover, it persisted, because after the war, two associations were re-established, where the anarchists dominated: the Union of North Bohemian Mining Unions and the Union of Socialist Non-Believers. ${ }^{22}$ Although some anarchists did not join the Socialist Party, there was no attempt between them to form an independent political organization. Thus, in 1919, the political current known as anarchists no longer existed in public life. Its former leaders had since then called themselves either Communists, Socialists, or Independent Socialists.

Whereas in 1919 the left-wing Czech, German and Slovak social democrats and some anarchists were transforming themselves into Czechoslovak communist party, the anarchists operating in the Socialist Party were only slowly moving to pro-Bolshevik positions. The reason was that, unlike the left wing of the Social Democrats, the anarchists saw the proclamation of the Czechoslovak Republic (ČSR) as the realisation of their dream, even though they soon began to disagree with many in the new state. In particular, they were bothered by the abandonment of plans to socialize the economy and the little measures taken against the Catholic Church, the nobility and the Habsburgs. ${ }^{23}$ On the other hand, they perceived the Bolshevik movements operating in the surrounding countries at the time as threatening to subvert Czechoslovakia. They therefore did not support the Hungarian Republic or the German Spartacus League, although they continued to sympathise with

and publisher of anarchistic literature. After military service in World War I, he along with Bohuslav Vrbenský joined the Socialist Party and was a deputy in the National Assembly. Already in 1921, he joined the KSČ and became its leading poet. In 1929, he was expelled expelled during the Stalinist turn (Bolshevization of the party). In addition to writing poems, he also wrote popular books on history. After 1945, he was celebrated as a leading national poet.

19 Kampan̆ proti dru Vrbenskému (The campaign against dr. Vrbenský). Červen, 1919, Vol. 2, No. 13, p. 119.

20 KLÁTIL, František: Republika nad stranami. O vzniku a vývoji československé strany národně socialistické (1897-1948) (Republic over Parties. On the emergence and development of the Czechoslovak National Socialist Party /1897-1948/). Melantrich, Praha 1992, p. 150

21 Sjezd českých anarchistů-komunistů (Congress of the Czech Anarchists-Communists). Červen, 1919, Vol. 2, No. 1, p. 9. The Federation of Anarchists-Communists emerged in 1914 from the initiative of Bohuslav Vrbenský and was to be an attempt at a political party. It was disbanded during the First World War, renewed in 1918.

$22 N A$, f. 1017, k. 82, Letter of Theodor Bartošek to the Union of Socialist Monists, $V$ důsledku společné porady (As a consequence of the joint meeting), typescript, 2. 12. 1918. Ibid. 
Bolshevik Russia, even if they claimed that Russian recipes were not feasible in our country. ${ }^{24}$

Based on these facts, the anarchists operated throughout 1919 and until about mid-1920 as a group essentially loyal to the state (with the exception of the radical group around S. K. Neumann). Their leader Vrbenský was repeatedly called to the governments, first as the Minister of Public Supply, then as the Minister of Public Works and finally as the Minister of Health. During his parliamentary career from November 1918 to March 1923, he thus held a ministerial post for a total of 23 months, i.e., almost half of the period. His supporters then often claimed that he had been silenced by ministerial posts, i.e., he could not stand at the head of the left wing of the party and as a minister he had to be more careful in his public speeches. On the other hand, thanks to his ministerial positions, he remained a prominent figure in public life.

Just before the elections in May 1920, the leadership of the Socialist Party preferred to maintain the influence of the Vrbenskýs group, as social radicalization had still not declined. For this reason, Vrbenský and three of his friends were elected again to the parliament. They were the pre-war anarchist and feminist activist Luisa Landová-Štychová (1885-1969), ${ }^{25}$ president of the association Free Thought and lawyer Theodor Bartošek (1877-1954) and newly the leader of the North Bohemian Mining Unions Václav Draxl (1874-1939) was added to them instead of Stanislav Kostka Neumann. Thus, the number of representatives of the anarchists did not decrease in the new National Assembly, although the Socialist Party now had only 24 seats compared to 35 in the Revolutionary National Assembly from 1918-1920. However, already during the year 1920, anarchists started leaving the Socialist Party for the left wing of the Social Democrats. The most important case was S. K. Neumann, who did so with his supporters associated in the Union of Communist Groups in May 1920. ${ }^{26}$ Also Luisa Landová-Štychová expressed this desire, although for the meantime she remained loyal to Vrbenský. ${ }^{27}$ The fact that the social democratic left was led by Bohumír Šmeral ${ }^{28}$, who was in the eyes of Vrbenský

24 NA, f. 1017, k. 80, Landová-Štychová Luisa: Kladensko! (Kladno region!), undated, approximately the middle of 1919, unpaginated.

25 See in more detail HOLUBEC, Stanislav: Neštastná revolucionářka. Myšlenkový svět a každodennost Luisy Landové-Štychové (Unhappy Revolutionary. The thoughts and everyday life of Luisa Landová-Štychová). NLN, Praha 2021.

26 MĚCHÝŘ, Jan: Hornický sever s komunisty. Příspěvek $k$ založení KSČ v severozápadních Čechách (Mining North with the Communists. A contribution to the founding of the KSČ in northeast Bohemia). Severočeské nakladatelství, Liberec 1961, Photographic appendix.

27 NA, f. 1017, k. 5, journal of Luisa Landová-Štychová from September 1920 - March 1922, record dated 20. 6. 1921, unpaginated.

28 Bohumír Šmeral (25. 10. 1880 - 8. 5. 1941), was a Czech lawyer, politician and journalist. Even before 1914 he was one of the leaders of the Czech Social Democrats and a member of the Austrian Parliament. During the First World War, he pursued a policy of cooperation with the monarchy. During 1918-1920, he led the left of the Czechoslovak Social Democracy and was the main founder of the Communist Party of Czechoslovakia. Thanks to him, this party did not initially choose a sectarian line, but became a mass movement that took over over majority of of the supporters of 
and others the embodiment of a pro-Habsburg collaborator from the war years, also played a role in the only slow rapprochement with the left wing of the Social Democrats. $^{29}$

The anarchists found themselves in a completely different situation after the clash between the right and left wings of the Social Democrats in December 1920, when they showed quite clearly their sympathy for the left wing. ${ }^{30}$ The group also moved significantly to opposition positions after police shootings into a crowd of strikers in the Slovak village of Krompachy in February $1921 .{ }^{31}$ It is also possible that the leadership of Socialist Party understood after the 1920 election that their bet on anarchists as a means of strengthening at the expense of social democracy had not worked out, that the radicalization of society was declining overall, and it was therefore necessary to get rid of Vrbenský and company. Luisa Landová-Štychová, a Member of Parliament who most loudly advocated the legalization of abortions, which probably frightened many moderate voters, probably also contributed to the further marginalization of the current within the Socialist Party. ${ }^{32}$ Therefore, the position of the Vrbenský group in the party leadership weakened after the party congress in May $1921 .^{33}$ The relations were further exacerbated by the fact that some party members attended communist meetings. In May 1921, the leadership of the Socialists had expelled several young activists, who had not adorned themselves with the national colours on the first of May, but with red poppies $^{34}$ and in November 1922 two pro-Communist leaders from Brno. ${ }^{35}$ Similarly,

the Social Democratic Party. From the mid-1920s, he served in the Comintern and his influence in Czechoslovakia waned. He died during World War II in Moscow.

$29 N A$, f. 1017, k. 5, diary of Luisa Landová-Štychová from September 1920 - March 1922, record dated 20. 9. 1920, unpaginated.

30 Ibid., record dated "December 1920", unpaginated.

31 Ibid., undated, approximately February 1921, unpaginated.

32 NA, f. 1017, k. 16, letter of the Regional Committee of the Czechoslovak Socialist Party for the Districts of Opava and Ratiboř addressed to Luisa Landová-Štychová, Vážená sestro! (Dear sister!), typescript, 10. 12. 1920, p. 1. In more detail, see ŽÁČKOVÁ, Zdeňka: Boj o paragraf 144. Potraty a legislativa za první republiky (Battle over Paragraph 144. Abortions and legislation under the First Republic). Acta Historica Universitatis Silesianae Opaviensis, No. 9. Slezská univerzita v Opavě, Opava 2016, pp. 55-78. Also FEINBERG, Melissa: Elusive Equality. Gender, Citizenship, and the Limits of Democracy in Czechoslovokia, 1918-1950. Pittsburgh University Press, Pittsburgh 2006, p. 132.

33 NA, f. Archiv České strany národně sociální (Archive of the Czech National Socialist Party, hereinafter only 1302), k. 17, sl. (document folder) 15a, Zastupitelstvo Československé strany národně socialistické, 15. 8. 1921 v Praze (ve Hvězdè). Protokol (Board of the Czechoslovak Socialist Party, 15. 8. 1921 in Prague /in Hvězda/. Protocol.).

34 NA, f. 1017, k. 5, diary of Luisa Landová-Štychová from September 1920 - March 1922, record dated 20. 5. 1921, unpaginated.

35 They were Vladimír Matula and Štěpán Dobrovolný. NA, f. 1302, k. 44, sl. Zápisy ze schůzí výkonného výboru (Minutes from the meeting of the executive committee), Zápis XXIX. schůze ústředního výkonného výboru strany konané 8.1.1923 (Minutes of the XXIXth meeting of the central executive committee of the party on 8. 1. 1923), typescript, unpaginated. See also NA, f. Ministerstvo vnitra I prezidium (Ministry of Interior I - presidium, hereinafter only 225), k. 605, No. 221/pres., Opozice v čs. straně socialistické v Brně. Zpráva (Opposition in the Czechoslovak Socialist Party. Report), 2. 3. 1923. 
the party leadership at the time explicitly banned MP Landová-Štychová from attending communist meetings. ${ }^{36}$

In this situation, it was clear to Vrbenský from October 1922, when he definitively lost his ministerial position, that he and those close to him no longer had a career in the Socialist Party and would no longer defend their parliamentary seats in the elections scheduled for 1925. At that time, Vrbenský probably began to lean toward the idea that it was high time to try to start a new party with the help of North Bohemian mining unions, atheist associations and socialist scouts loyal to him led by Jaroslav Štych, Landová-Štychová's husband. Vrbenský may have thought that the creation of the party would take many months, and if he wanted to participate with it in the 1925 elections, its foundation could not be postponed. It was still inconceivable for him to join the Communists, because he was internally too attached to the recently formed republic. Nevertheless, the contacts of Vrbenský's group with the Communists already existed on a personal level, such as Luisa Landová-Štychová's friendship with Communist Party leaders Bohumír Šmeral and Josef Haken or the participation of medical student Miloslav Matoušek in the Socialist Society, an intellectual association founded in May 1921 by the Communists, left-wing Social Democrats and anarchists. ${ }^{37}$ The fact that there was still a fourth party on the left, the so-called Independent Social Democrats, i.e., three deputies of the Social Democrats (see below), who did not join either the left or the right wing during the split in 1919-1920 and tried unsuccessfully to build their own subject, may have played a role in Vrbenský's decision-making. As journalist Ferdinand Peroutka claimed, from the end of 1922, Vrbenský and those close to him awaited a suitable moment when they could leave the Socialist Party. ${ }^{38}$ The assassination of the Minister of Finance Alois Rašín at the beginning of January 1923 and the subsequent approval of the law for the protection of the republic was the final drop in their decision.

At the beginning of February, Vrbenský and others became acquainted with the hitherto top-secret draft of this law, which somehow got into the editorial office of the communist daily Rudé právo (Red Truth)..$^{39}$ The bill provided for relatively heavy penalties for acts such as high treason, violent constitutional change, separatism, perversion or hindrance of the activities of the constitutional authorities, insult of the president, illegal armaments, espionage and preservation or installation of Habsburg monuments. The radical left could, in particular, be concerned with the

36 NA, f. 1017, k. 147, letter of the Central Executive Committee of the Czechoslovak Socialist Party to Luisa Landová-Štychová, Vážená sestro, typescript, 22. 11. 1922.

37 KŘESŤAN, Jiří: Zdeněk Nejedlý a spolek socialistická společnost v Praze (Zdeněk Nejedlý and the Socialist Society Association in Prague). Paginae historiae, 2001, No. 9, pp. 225, 227.

38 PEROUTKA, Ferdinand: Budování státu, díl IV (Building the State, Vol. IV). Lidové noviny, Praha 1991, p. 1710.

39 Doslovné znění persekučního zákona připravovaného vládními stranami (Literal wording of the persecution law prepared by the government parties). Rudé právo, 8. 2. 1923, p. 1. 
illegal association with conspiracies of the Republic.40 The paradox was that Vrbenský et al. originally supported the idea of a law to protect the republic, because it was to be directed against nostalgia for the Habsburgs. ${ }^{41}$

At that time, the group probably sensed a good opportunity to leave the Socialist Party. They might have anticipated that voting against the bill would cost them parliamentary seats - unlike the left-wing Social Democrats, who were not deprived of their seats two years ago after a rift with the party leadership, apparently because there were too many. ${ }^{42}$ However, they might have thought that if they started a factional withdrawal now, they would have plenty of time to build a new party and return to parliament two years later. They might have also anticipated that exclusion from the parliament would assure them the aureole of martyrs and thus the sympathy of the voters. The speed with which only a few days after their March expulsion they began to issue the daily Československý socialista (Czechoslovak Socialist ${ }^{43}$, into which Vrbenský invested his savings from the time he was a minister ${ }^{44}$ indicates that they had prepared their fractional withdrawal already in the preceding weeks.

The decisive dispute in the Socialist Party began with the fact that the Socialist Party's daily České slovo (Czech Word) under the leadership of editors Vlastimil Borek and Josef Kozák was campaigning against the bill of the law for the protection of the republic. The party leadership therefore decided to recall and dismiss them..$^{45}$ At the meeting on 29 February, Vrbenský opposed this and ultimately declared that either the dismissal of the editors of České slovo would be revoked or he and his group would leave the party. On the contrary, the leader of the right-wing of the party, Jiří Stříbrný, threatened that if the editors were not fired, he would resign his seat in parliament. In the ensuing vote, the party leadership favoured the decision to dismiss the editors with a vote of 22:7. Then, Vrbenský and three other members left the meeting demonstratively. A few days later, on 5 March, Vrbenský declared that since the decision to dismiss them had not been revoked, he and other deputies were entering an open struggle in the party. ${ }^{46}$

40 Zákon na ochranu republiky (Act on Protection of the Republic) - see https://cs.wikisource.org/ wiki/Z\%C3\%A1kon_na_ochranu_republiky (quoted version dated 16.12. 2021).

41 HAMŠÍK, Dušan: Louisa Landová-Štychová. Mladá fronta, 1. 2. 1950, p. 5.

42 Even the pro-government press at the time of the exclusion of Vrbenský et al. assumed they would lose their seats. See Ochranné zákony ve sněmovně schváleny (Protective laws approved in the chamber). Lidové noviny, 7. 3. 1923, afternoon edition, p. 1.

43 Československý socialista. Nezávislý list československých socialistů, 14. 3.1923 (first Number).

44 KLÁTIL, František: Republika nad stranami, p. 154

45 NA, f. 1302, k. 44, sl. Zápisy ze schůzí výkonného výboru, Zápis XXXI. schůze ústředního výkonného výboru strany konané 26. 2. 1923 (Minutes of the XXXIst meeting of the Central Executive Committee of the Party on 26. 2. 1923), typescript, unpaginated.

46 Ibid., Zápis XXXII. schůze ústředního výkonného výboru strany konané 5. 3. 1923 (Minutes of the XXXII meeting of the Central Executive Committee of the Party on 5. 3. 1923), typescript, unpaginated. 
In the days preceding the parliamentary vote, Vrbenskýs group tried to campaign against the bill of the law among the party members, at a conference of the North Bohemian party regional organisation they even passed a resolution calling on deputies to reject the bill. ${ }^{47}$ In the parliamentary club and the constitutional law committee, they tried to change the bill in cooperation with other left-wing deputies, and in some details they succeeded. At the end of the meeting of the club and committee, the lawyer and deputy Theodor Bartošek even declared apparently that after accepting two of his amendments he would vote for the bill. ${ }^{48}$ However, when the bill was ready and approved by all of the parliamentary clubs and committees, Vrbenský again proposed at the meeting of the club on 6 March another 23 amendments, which most of his colleagues rejected. Vrbenský's group thus decided to submit amendments independently at the plenary session of the Chamber of Deputies, but this required a larger number of signatures from deputies - they received them from the Communists. ${ }^{49}$ This and not voting against the law itself became the reason for the exclusion of Vrbenský et al. ${ }^{50}$ The press, loyal to the party leadership, wrote that the group had allied with communist, German and Hungarian deputies. ${ }^{51}$

The parliamentary session of 6 March 1923 was very tumultuous. Communist deputies in particular disrupted it so much that six of them had to be taken out of the hall by the parliamentary guard and banned from attending several other sessions. ${ }^{52}$ The Communists also tabled a number of amendments, which were rejected by other parties. ${ }^{53}$ Then Theodor Bartošek took the floor and also tabled his own amendments on behalf of Vrbenský and others. Immediately afterwards, his speech was rejected by the chairman of the Socialist Club. A vote followed and the bill was approved by a majority in the Chamber of Deputies. Slovak Catholic nationalists (Slovenská ludová strana / Slovak People's Party) and German deputies did not participate, the communists and four socialists, Bartošek, Draxl, Vrbenský and Landová-Štychová, voted against. Of the 24 Socialist deputies, some others sympathised with this group, but they voted in favour of the bill and remained in the party. Of the senators, the former realist František Krejči supported Vrbenský's group, but he also did not decide to vote against it. Still that same day, the So-

47 TŮMA, Jiř́: Bohuslav Vrbenský, p. 74.

48 Řeč ministra br. Stř́ibrného před sborem důvěrníků čsl. strany socialistické v Plzni (Speech of the Minister Brother Stríbrný before the Board of Confidants of the Czechoslovak Socialist Party in Pilsen). Český směr. Deník Československé strany socialistické na českém západě, 16. 3. 1923, p. 1.

49 Stoupencům českoslov. stany socialistické (Supporters of the Czechoslovak Socialist Party). Český směr. Deník Československé strany socialistické na českém západě, 8. 3. 1923, p. 1.

50 Masky padly (The masques fell). České slovo, 7. 3. 1923, večerník (evening edition), p. 1. It seems that the intention of statement was to provoke the public against Vrbenský by the mention of Germans and Hungarians in particular, while it was not mentioned that they belonged to the communist club.

51 Ibid.

52 MALÁ, Jaroslava: Zákon na ochranu republiky (diplomová práce) (Act on the Protection of the Republic /Thesis/). Právnická fakulta Univerzity Karlovy, Praha 2011, p. 26.

53 Politika (Politics). Nová doba, 8. 3. 1923, p. 3. 
cialist Parliamentary Club expelled the four deputies (18 in favour, six against). In addition to the expelled, deputies Jindřich Trnobranský and Emil Špatný, who were imprisoned with Vrbensky during the war and were thus close to the anarchists, probably voted against the expulsion. Three other deputies sympathised with the group, but they eventually voted for expulsion..$^{54}$

Subsequently, the four were also expelled from the party by the executive committee on 8 March (25 in favour, six against). ${ }^{55}$ Moreover, the leadership immediately expelled also the four members of the committee, who had voted against the proposal: Miloslava Hrdličková-Šrámková, editor of the women's supplement of the party daily České slovo and the partner of Frána Šrámek ${ }^{56}$, the metalworker and trade unionist Josef Danda, editor Vlastimil Borek and the official Jaroslav Štych. Vrbenský, who was already expelled, was the fifth to vote against, and Františka Plamínková, ${ }^{77}$ a feminist, was sixth, but her membership in the party was maintained and the executive committee stood up for her even a few months later when party members from Prague tried to expel her...$^{58}$ The group of expelled officials appealed against the decision to the party's central committee, but on 19 March it confirmed that the expulsions were valid (117 in favour, six against). At the same time, the editors of České slovo Josef Kozák and Jaroslav Kraus were also expelled from the party.

Already on 22 March 1923, the expelled deputies joined the group of three Independent Social Democrats (see above) ${ }^{59}$ which, however, had only gained a few thousand members in previous years. ${ }^{60}$ With these deputies, the Vrbenský group now formed a club called the Socialist Unification. Two years later, Landová-Štychová stated that after the expulsion, she proposed that all four join the club of communist deputies. ${ }^{61}$ The communist press wrote about this group's factional withdrawal

54 MAREK, Pavel: Čeští anarchokomunisté, p. 757.

55 The historian Jiří Tůma presents a somewhat different number. TŮMA, Jiří: Na cestě ke komunistické straně (On the Way to the Communist Party). Severočeské nakladatelství, Ústí nad Labem 1975, p. 104.

56 Fráňa Šrámek (19. 1. 1877 - 1. 7. 1952), was a leading Czech poet and author, sympathiser with anarchism known for his anti-militaristic poetry.

57 Kdo hlasoval pro vyloučení dra. Vrbenského ze strany? (Who voted to expel Dr. Vrbensky?) Český směr, 10. 3. 1923, p. 2.

58 NA, f. 1017, k. 15, letter of Luisa Landová-Štychová to the official of the KSČ Šmidrkalová, Vážená soudružko Šmidrkalová (Dear Comrade Šmidrkalová), typescript, undated, approximately 19451946, p. 2. The central executive committee of the party rejected the expulsion of Františka Plamínková in August 1923 by a vote of 26 to 3. NA, f. 1302, k. 44, sl. Zápisy ze schůzí výkonného výboru, Zápis XXXV. schůze ústředního výkonného výboru strany konané 31. 8. 1923 (Minutes of the XXXVth meeting of the Central Executive Committee of the Party on 31. 8. 1923), typescript, unpaginated.

59 Deputies Vilém Brodecký, Vincenc Charvát, Robert Klein. See TŮMA, Jiři: Bohuslav Vrbensky, p. 82.

60 Poslanecká sněmovna (Chamber of Deputies). Československá republika, 24. 3. 1923, p. 2.

61 Státní okresní archiv (State District Archive, hereinafter only SOkA) Kladno, f. Landová-Štychová Luisa (hereinafter only 1669), Luisa Landová-Štychová, Zápisy ze schůze Ústřední rady žen nezávislé socialistické strany (Minutes from the meeting of the Central Council of the Women of the Independent Socialist Party), manuscript, 22. 11. 1924, 1. (sheet) 27. 
with sympathy, although it did not call them to join the KSČ. ${ }^{62}$ Although it was the Communists who proposed Vrbenský as prime minister at the time of the split in the Social Democrats, ${ }^{63}$ their attitude towards him was distrustful. For them, he was primarily a representative of several bourgeois cabinets, and moreover they were aware of the rejection of anarchists by the Russian Bolsheviks.

\section{Attempt to create the Party of Independent Socialists and merger with the KSČ}

Shortly after their expulsion from the Socialist Party, Vrbenský and others began to build a new political group, which they called the Independent Czechoslovak Socialist Party. From the very beginning, Vrbenský appeared as chairman and Landová-Štychová as vice-chairwoman. In period terminology, the adjective "neodvislá" (independent) meant the same thing as opposition to the original party. The name Independent Socialists was used by anarchists before the war. ${ }^{64}$ Then in 1917 this nickname was used by the anti-war German Social Democrats, who under the name Unabhängige Sozialdemokratische Partei Deutschlands/USPD (German Independent Social Democracy) founded an opposition party different from the historical social democrats, loyal to the empire and hence dependent on it. Following their model, the adjective was chosen also by a small group of Czech social democrats, who separated from their party in 1920 but did not join the KSČ. Their name, as well as the anarchist tradition, then inspired Vrbenský et al.

On 12 and 13 May 1923, they organized a regional meeting of the new entity in Louny, where they traditionally had many adherents. It was attended by 103 delegates, who according to their own claim were to represent 6,000 members. ${ }^{65}$ A few days later, the federation of the Vrbenský group and the Independent Social Democrats, which they called the Socialist Unification, was formed following the example of the parliamentary group and declared their intention to transform it into a unified political party in the future.

The new subject declared the ambition to be the basis for future cooperation of the KSČ, social democrats and socialists. Such a plan was, of course, impossible, because the trenches between the communist and the centre left were already too deep in the Czechoslovak Republic. Moreover, even if the leaders of the main left-wing parties had wanted to cooperate, cooperate, they would not have chosen

62 NEUMANN, Stanislav Kostka: Masky padly. Rudé právo, 7. 3. 1923, p. 1.

63 KLIMEK, Antonín: Boj o hrad 1. Hrad a pětka. Vnitropolitický vývoj Československa 1918-1926 na půdorysu zápasu o prezidentské nástupnictví (Battle for the Castle I. The Castle and the Five. The Internal Political Development of Czechoslovakia 1918-1926 on the Layout of the Battle for Presidential Successorship). Tomáš Krsek, Buková u Příbrami 2017, p. 145.

64 VESELÝ, Pravoslav A.: Omladina a pokrokové hnutí. Trochu historie a trochu vzpomínek (The Youth and Progressive Movements. A little history and a little memoirs). Vlastním nákladem, Praha 1902, p. 28.

65 TƯMA, Jiř́i: Bohuslav Vrbenský, p. 84. 
a platform as a platform as marginal as the Vrbenský group. The only chance for the Independent Socialists was to get as many members and voters of the Socialist Party as possible, dissatisfied with its direction to the right and at the same time reluctant to support the KSČ, which they perceived as anti-Czechoslovak and too radical.

The first blow to the emerging party came early. On 31 March, the executive committee of the Socialist Party asked the electoral court, which in the constitutional system of the Czechoslovak Republic was the institution verifying the validity of the mandates of deputies, to remove the expelled deputies from their seats in the parliament. In its request, the party leadership claimed that Vrbenský et al. had violated the agreement that they had signed before their election in 1920. It stated: The undersigned accepts the candidacy for the Chamber of Deputies and declares that if elected he/she will follow the principles, programme and organizational rules of the Czechoslovak Socialist Party and undertakes to act and vote in accordance with the resolutions of the Central Executive Committee and the Club in the Chamber of Deputies. In the event of a breach of the above-mentioned obligations, he/she declares that when called upon by the wider executive committee of the Czechoslovak Socialist Party he/she will resign his/her mandate at any time. ${ }^{66}$ The electoral court discussed the matter for almost three months, which might have aroused hope in Vrbenský et al. that they would be able to remain in parliament, but they were all removed from their seats on 22 June 1923. The Electoral Court based its decision on a passage of the law, according to which a deputy loses his mandate if he ceases to be a member of the party from whose list of candidates, he/she had been elected for low and dishonest reasons. ${ }^{67}$ For these reasons, the electoral court meant a violation of the agreement signed before the 1920 election.

In a letter against the decision, Landová-Štychová argued firstly that the basic formulation of the undertaking had been observation of the electoral programme. Secondly that she had signed the document only as a mere formality, because I also assumed the same loyalty to the party's principles and programme from its central committee. ${ }^{68}$ Thirdly that the undertaking was in contradiction to the deputy's oath where she promised to adhere to the seat according to his/her best conscience. ${ }^{69}$ Finally and fourthly she emphasised that the undertaking represented a departure from the parliamentary principle that a majority of all deputies should decide: compliance with the majority requirement in clubs would mean that the government could only rely on 81 and not at least 151 of 300 deputies. $^{70}$

66 Ibid.

67 NA, f. 1017, k. 11, Naléhavá interpelace poslanců panu ministerskému předsedovi a vládě Československé republiky o porušení ústavy volebním soudem (Urgent interpellation of deputies to the Prime Minister and the Government of the Czechoslovak Republic on violations of the Constitution by the electoral court), typescript, roughly March 1923, unpaginated.

68 Ibid., letter by Luisa Landová-Štychová to Electoral Court, Volebnímu soudu v Praze (to the Electoral Court in Prague), undated, roughly June 1923, p. 3.

69 Ibid., pp. 3-4.

70 Ibid., p. 5. 
The decision of the Electoral Court became an important precedent, as until now the deputies have not been deprived of their seats for resignation/expulsion from the party. For instance, the Christian-Social oriented Czechoslovak People's Party had not tried to deprive its Slovak colleagues, who stood for election with it in 1920, of their parliamentary seats, but after the elections they decided to create their own parliamentary club. Similarly, even after the rift with their party leadership, not even the left-wing Social Democrats had been deprived of their seats. The press that sympathised with the Vrbenský group called the court's decision a constitutional coup: This has, in fact, been a breakthrough in the principle that deputies decide in the Chamber only to the best of their knowledge and conscience, as those who disobey their party's executive committee may be recalled at any time to make a seat for deputies willing to make any vote. ${ }^{71}$

When the group lost their seats in June 1923, the former deputies had to find jobs. Moreover, along with that, they also lost their free train tickets and so could not visit the party organisations outside Prague as often. Luckily, the family of Lusia Landová-Štychová was kept afloat by the income of her husband Jaroslav, who was an official at the Prague magistrate. Vrbenský, however, had to work as a dentist again and Bartošek returned to his legal practice, because of which less time remained for politics. The official of the mining unions Draxl had his main base in North Bohemia and did not want to intervene in nationwide politics. By the autumn only about 15,000 members of the Socialist Party had joined Vrbenský et al., ${ }^{72}$ which was more than the number of anarchists who joined the party in 1918, but only a tenth of its membership base. From their membership fees, the party press was mainly subsidized and its editors paid, but there was nothing left for paying for a larger professional party apparatus or renting offices, so the party leadership held its meetings in rented pub halls. During the fall 1923 it was possible to claim that the project had ended in failure and that if the party were to go into the election in 1925 independently, that it would be able to hope only for the election of Vrbenský in the North Bohemia District.

In September 1923, the Independent Socialists participated in the municipal elections in Prague and other parts of the republic. They won in them two hundred municipal representatives and nine mayors of smaller municipalities, mainly in the North Bohemia District ${ }^{73}$ and the Brno District. These results clearly demonstrated that the party was virtually non-existent in other parts of the republic, and there was no hope it could be changed. They were rarely elected in larger towns

71 Povýšili jste moc nad právo, porušili jste ústavu - my si ji zase dobudeme (You raised power over the law, you have violated the constitution - we will seize it again). Vpřed. Župní orgán nezávislé Československé strany socialistické (Socialistické sjednoceni), 5. 7. 1923, p. 1.

72 Ibid., s. 95.

73 NA, f. 1017, k. 176, Zpráva ústředního sekretariátu nezávislé socialistické strany dělnické $\mathrm{v}$ Československu (Report of the central secretariat of the Independent Socialist Labour Party in Czechoslovakia), 1925 (more closely undated), unpaginated. 
in other regions. ${ }^{74}$ As a result of the election failure, the party leadership reduced the scope of the Czechoslovak Socialist daily (later renamed the Socialist) to two printed pages and changed it to a weekly newspaper from December. These municipal elections were the first to take place after the unification of inner Prague with the surrounding municipalities, when the capital gained roughly today's size. The Socialist Unification put up three dozen candidates here, while the big parties had over a hundred. Vrbenský led the list of candidates, Landová-Štychová was in second place. ${ }^{75}$ Only Vrbenský was elected, but he resigned his mandate in December. He explained it as being for medical reasons, but maybe he wanted to have time to run the party. So Landová-Štychová took his place and, like him, joined the communist faction. ${ }^{76}$ Thanks to the support of the communists, it was possible to push an official of the Prague City Hall, Jaroslav Štych, as an expert into the civil engineering commission of the council. ${ }^{77}$

The programme of the Party of Independent Socialist is mainly interesting for the fact that feminism appears in it, which otherwise did not penetrate too much into the programmes of the Czechoslovak parties. Anarchists did not promote a much feminist program before the war (e.g., it did not appear in the programme declaration of the Federation of Anarchists-Communists ${ }^{78}$, but was written about in anarchist papers) and it came to be in the programme of the Independent Socialists thanks to Landová-Štychová and her wartime contacts with the feminist movement around Františka Plamínková. For instance, the party was the only one then to push for gender quotas. In the draft of its statutes, it stated: Always have at least as many women elected to all the committees of the party as they have in percentage to men in the membership. If the trustee of a local, district or county organization is a male man, let his deputy be a female if possible. ${ }^{79} \mathrm{On}$ the candidate lists in the municipal elections, women were also to be represented in proportion to the membership, and one of the two vice-presidents of the party always had to be a woman.

The party clearly had an anti-capitalist profile, but differed from the communists in that it wanted to promote socialism in a peaceful and not revolutionary way. ${ }^{80}$

74 They gained one mandate each in Pardubice, Tábor, Nymburk and Mladá Boleslav. See Výsledky v obcích, kde jsme se voleb zúčastnili a pokud jsou nám známy (Results in municipaliteis where we participated in the elections and if they are known to us). Socialista, 18. 9. 1923, pp. 1-2.

7515 kandidátních listin v Praze. Výsledky voleb. (15 lists of candidates in Prague. Election results). Národní listy, 3. 9. 1923, p. 1.

76 Resignace dra Boh. Vrbenského (Resignation of Dr. B. Vrbenský). Národní listy, 6. 11. 1923, p. 3.

77 Archiv hlavního města Prahy (Archive of the Capital City of Prague), f. Magistrát hlavního města Prahy I. (Magistrate of the Capital City of Prague I) (zn. 4), Protokoly schůzí ústředního zastupitelstva ŕíjen - prosinec 1923 (Protocols of the meetings of the Central Representation October - December 1923), inv. č. (inv. No.) 870, 15. 10. 1923, p. 19.

78 TOMEK, Václav: Český anarchismus, p. 73.

79 NA, f. 1017, k. 125, Návrh organisačního řádu strany, Korespondence Socialistického sjednocení (Proposal of the organisational council of the party, Correspondence of the Socialist Unity), No. 4 (June 1924), p. 4.

80 TŮMA, Jiř́i: Bohuslav Vrbenský, p. 94. 
It expressed loyalty to the state, unlike the then Communist Party, it would not accept the secession of territories inhabited by national minorities and maintained respect for President Masaryk. Nevertheless, what is surprising is the minimal emphasis on democracy and the lack of mechanisms of intra-party democracy in the statutes, which, for example, did not address how candidate lists were created and their creation was probably the responsibility of the party presidency, as in the case of other Czechoslovak political parties. Over time, the party became somewhat radicalized and approached the KSČ, which is clear from the fact that after a year of its existence it abandoned the old national socialist address of brothers and sisters and decided to use the address male and female comrades, which was used among the Social Democrats and in the KSČ. ${ }^{81}$ Unlike the Communists, the party did not try to gain members among national minorities and wanted to expand only in Slovakia. The proposal that it should be opened to the Germans and Hungarians remained unanswered. ${ }^{82}$

In terms of international relations, it sought to establish cooperation with parties that rejected the reformist policies of the Social Democratic Parties and at the same time did not want to submit to Moscow's Third International (Comintern), the most important of which was the German Independent Social Democracy. These parties founded the so-called Two-and-a-half International in February 1921. Vrbenskýs party only joined it in May 1923, when this organisation was already heading to the centre and merging with the Social Democratic Second International, which also included the Czech Social Democrats. The German Independent Social Democrats then quickly fell apart and their members either joined the Communists or returned to the Social Democrats. Whereas in the June elections of 1920 they took 18 percent of the votes, four years later they fell to not quite one percent. It clearly showed in Germany as everywhere in Europe then that there was not room for another political force between the Communists and the Social Democrats.

The relative failure of the Socialist Unification in the autumnal municipal elections of 1923 and tendency of their leadership to ever more orientate on cooperation with the Communists led the Czech Independent Social Democrats to the opinion that the creation of a joint party did not make sense. In the summer of 1924, they definitively rejected a fusion with Vrbenský's party ${ }^{83}$ and in September these three deputies returned to the old Social Democrats. They were welcomed here with open arms on the whole, and the Social Democrats had two of them re-

81 SOkA Kladno, f. 1669, Luisa Landová-Štychová, Zápisy ze schůze Ústřední rady žen Nezávislé socialistické strany, červenec 1924 - záŕí 1925 (Minutes from the meeting of the Central Council of Women of the Independent Socialist Party, July 1924 - September 1925), manuscript, 1. 24.

82 NA, f. 1017, k. 46, MATOUŠEK, Mil[oslav].: Socialistické sjednocení a národnosti Československa (Socialist Unity and the Nationalities of Czechoslovakia). Nové proudy. List mládeže Socialistického sjednocení, 3. 10. 1923, pp. 1-2.

83 Sjezd zbytečné strany (Congress of an excess party). Nová doba, 2. 7. 1924, p. 3; Sjezd strany Socialistického sjednocení (Congress of the party of Socialist Unity). Rudé právo, 1. 7. 1924, p. 1. 
-elected to parliament in the 1925 elections. The Social Democrats were willing to take the group back because the Communists were their main enemy and wanted to weaken their influence.

It was mainly Landová-Štychová, who promoted approaching the KSČ within the Independent Socialists, and besides here also Vlastimil Borek, Theodor Bartošek, student of the Law Faculty Ivan Sekanina (1900-1940) or the medical student Miloslav Matoušek (1900-1985). Although it seemed too slow to this group, none of them went to the Communist Party on their own, and almost all remained loyal to Vrbenský. One of the few exceptions was the Moravian activist Vladimír Matula (1894-1975), who joined the KSČ already at the end of $1923 .{ }^{84}$

In the middle of 1924, the party leadership was already aware of the project's failure. In addition to the loss of interest of the Independent Social Democrats, it turned out that the membership base had decreased from 15,000 to 10,000 in a year. ${ }^{85}$ At the beginning of October 1924, however, the leaders still did not indicate their intention to dissolve the party. At the women's meeting, Landová-Štychová gave two reasons for its existence. On the one hand, it was said that it was necessary to somehow capture organisationally the citizens disgusted by the politics of the socialist parties, who did not want to or could not join the Communists (because of their work in the civil service). The second reason is more interesting and Landová-Štychová no longer mentions it in her later texts: The dissolution of the Communist Party is being considered in government circles. The possible acceptance of Moscow's national theses (on the right of minorities to secede - author's note) at the upcoming congress of the KSČ is to be used as the reason. ${ }^{86}$ In that case, the right moment of the Independent Socialists might come. However, only a few days later, on 10 October, Vrbenský proposed at a meeting of the presidency to disband the party and call upon the members to join the KSČ. The others agreed and the proposal was referred to discussion by the enlarged presidency, but the public was not yet notified. A month later, this proposal was discussed by the enlarged presidency, which also approved it, but with the matter remaining secret for the time of negotiations with the communists and that the party should seek some variant of collective integration into the Communist Party and not take the humiliating path of self-dissolution and joining of individual members. ${ }^{87}$

At a meeting of the Council of Women of Independent Socialists at the same time, its chairwoman, Zdena Soldanová, spoke about the party's crisis and the need to join the KSČ. However, it was said in the discussion that a large part of the mem-

84 Archiv Ministerstva zahraničních věcí (Archive of the Ministry of Foreign Affairs), f. Osobní spisy II (54) (Personal Files II), k. 599, sl. Vladimír Matula, Opis Vladimír Matula Životopis (Copy Vladimír Matula CV), typescript, 21. 1. 1953, p. 2.

85 TŮMA, Jiří: Bohuslav Vrbenský, p. 95.

86 SOkA Kladno, f. 1669, Luisa Landová-Štychová, Zápisy ze schůze Ústřední rady žen nezávislé socialistické strany (Minutes from the meeting of the Central Council of the Women of the Independent Socialist Party), manuscript, 4. 10. 1924, 1. 24.

TŮMA, Jiří: Bohuslav Vrbenský, p. 96. 
bers did not want to join the Communists. One of those present emphasized that the Communist Party was in bankruptcy and that 40,000 members had left the party as a result of Moscow's interference. Landová-Štychová replied that the situation in the Communist Party would not be pleasant and easy for us in the present circumstances, but $[. .$.$] even if it diminished, it would still remain the only instrument$ of the proletariat against reaction and capitalism. Therefore, according to her, it was necessary to provide it with moral reinforcements through our corporate entry (that is collective joining - author's note). ${ }^{88}$ Moreover, the outflow of communist membership allegedly did not matter, as the party became more actionable. Another present suggested urging the leadership to try to keep the party and, if that was not possible, not to recommend members which new party to join. But most of those present were not for this proposal. ${ }^{89}$

In February 1925, the Independent Socialists requested the collective membership in Comintern.${ }^{90}$ It was not possible to apply for admission to the Czechoslovak Communist Party itself, as it was not allowed to decide on such issues. However, the Comintern had the principle that only one political entity may be a member in one state. Therefore, it was clear that the request meant a merger with the Czechoslovak communists. The number of members of the Independent Socialist Party continued to decline, and a report of activities in September 1925 stated that the membership made only 4,136 people. ${ }^{91}$ Membership fees for 1924 amounted to Czechoslovak crowns (Kč) 43,000, so one member paid an average of ten crowns. The party received another CSK 40,000 in extraordinary contributions from three of its deputies, Brodecký, Charvát and Klein, who turned away from it in the middle of the year and returned to social democracy (see above) and other donations. According to the report, it was very strongly atheistic, with 95 percent of its members without a confession, which undoubtedly differed from the Socialist Party and probably from the Social Democrats. Women formed a quarter of the membership. The party had influence in the Trade Union of Czechoslovak Miners based in Most. It published the weekly Socialista and two weeklies in its bastions, in Louny and in Dvưr Králové. ${ }^{2}$

Vrbenský informed the public of the plan to merge with the KSČ in June 1925 at a conference in Louny. ${ }^{93}$ In the summer, the party was informed by the Comintern

88 SOkA Kladno, f. 1669, Luisa Landová-Štychová, Zápisy ze schůze Ústřední rady žen nezávislé socialistické strany (Minutes from the meeting of the Central Council of the Women of the Independent Socialist Party), manuscript, 22. 11. 1924, 1. 28.

89 Ibid.

90 TŮMA, Jiř́i: Bohuslav Vrbenský, p. 100

91 NA, f. 1017, k. 176, Zpráva ústředního sekretariátu nezávislé socialistické strany dělnické v Československu (Report of the Central Secretariat of the Independent Socialist Labour Party in Czechoslovakia), 1925 (more closely undated), unpaginated.

92 They were Dvưr Králové's Vpřed. Župní orgán nezávislé Československé strany socialistické (Socialistické sjednoceni) and Louny's Duch českého severu. List Nezávislé československé strany socialistické pro VI. župu.

93 TŮMA, Jiří: Bohuslav Vrbenský, p. 101. 
that it could join, and then announced its departure from the Socialist International. Still in September, however, a member of the party's women's commission disagreed with the move, calling it undemocratic and forced. ${ }^{94}$

The Congress of Independent Socialists convened in Prague on 26-27 September 1925 and adopted the proposal to join the KSC.. ${ }^{95}$ None of the delegates voted against ${ }^{96}$ and the party presented this fact with pride in the press release. Probably those who had a different opinion either did not come to the congress at all, because they understood that their position was a minority, or they did not find the courage to express disagreement. The representative of the KSČ present, Anna Křenová, informed the assembled that they were joining it at a time when our party cannot guarantee any material gain to any of you and when the only sinecure that awaited you was the dungeon..$^{97}$ The Congress of the Communist Party took place on the same day in Prague. At its conclusion, Vrbenský came to it and announced the decision of his party. ${ }^{98}$ However, individual Independent Socialists did not become members automatically, and everyone had to apply for admission to a local Communist Party organization according to their place of residence and place of work. Thus, from the beginning, they were prevented from forming a faction in the party.

Most of the significant members of the Independent Socialists joined the KSČ..$^{99}$ However, for instance, Miloslava Hrdličková-Šrámková or the president of the women's commission Zdena Soldanová did not do so. The former deputy Václav Draxl went to the Social Democrats ${ }^{100}$ and the editor Josef Danda returned to the National Socialists. Almost none of the former Independent Socialists have had a brilliant career in the Communist Party. After the merger of both parties, none of them was elected to the nine-member executive committee (politburo) of the Communist Party or to its 30-member central committee. ${ }^{101}$ Only Landová-Štychová was offered membership in the executive committee, but she refused because she was

94 SOkA Kladno, f. 1669, Luisa Landová-Štychová, Zápisy ze schůze Ústřední rady žen nezávislé socialistické strany (Minutes from the meeting of the Central Council of the Women of the Independent Socialist Party), manuscript, 25. 9. 1925, 1. 34. Landová-Štychová did not agree with it and claimed that the majority of the local organisations expressed unanimous agreement with merger with the KSČ. Ibid.

95 TŮMA, Jiř́: Bohuslav Vrbenský, p. 102.

96 Sjezd nezávislé socialistické strany dělnické v Československu (Congress of the Independent Socialist Labour Party in Czechoslovakia). Socialista, 3. 11. 1923, p. 5.

97 KMONÍČEK, Josef: O životě Petra Pecha (On the Life of Petr Pech). Kruh, Hradec Králové 1978, p. 74.

98 TŮMA, Jiří: Bohuslav Vrbenský, p. 103.

99 LANDOVÁ-ŠTYCHOVÁ, Luisa: První socialistický popularisátor astronomie ing. Jaroslav Štych (The First Socialist Populariser of Astronomy, ing. Jaroslav Štych). Nová skutečnost, 1952, Vol. 6, No. 1, p. 7.

100 KOUKAL, Pavel: Václav Draxl. Masarykova demokratická akademie, Ústí nad Labem 2010, p. 47.

101 ŠTVERÁK, František: Schematismus $k$ dějinám komunistické strany Československa (1921-1992). Základní informace o ústředních orgánech a biografické údaje o vedoucích představitelích strany (Schematism of the history of the Communist Party of Czechoslovakia /1921-1992/. The basic information on the central bodies and biographical data on the leading representatives of the Party). NA ČR, Praha 2010, p. 42. 
convinced that Vrbenský should be in this body in particular: [...] The trust shown to me is a stimulus for further hard work, but my candidacy instead of comrade Vrbenský to the executive committee was in my judgement a serious error for the further fight in the north [of Bohemia...], therefore I cannot under these circumstances accept it. ${ }^{102}$ As a result, neither of them was invited to the party leadership.

We do not know how many regular Independent Socialists joined the KSČ or how long they remained there. After all, the Communist Party was then characterized by a large turnover of members. ${ }^{103}$ According to the data from 1925-1926, the total number of their members was around 90,000 and several thousand Independent Socialists was insignificant in them. ${ }^{104}$ The Union of Socialist Non-Believers also joined the communist atheists. ${ }^{105}$

The merge of the Independent Socialists with the Communists was planned as part of the Communist Party's election campaign, as a month later, on 15 November 1925, parliamentary elections were held. Of the former independent socialist leaders, only Landová-Štychová, who had earned the trust of communists in previous years, ran for the party. She was placed third at the candidate list in the Prague Region, headed by the trade union leader Antonín Zápotocký (after 1948 communist Prime Minister and President.) Landová-Štychová actually got into parliament, but she was disappointed by her own election campaign, because members of the Communist Party looked on the former Independent Socialists with distrust. ${ }^{106}$

It is possible that Vrbenský assumed that he would be accepted in the Communist Party with similar open arms as before by the National Social Party. However, 1925 was not 1918. At the end of the war, the Czech anarchists were a profitable acquisition for the national socials in the general wave of radicalization, and although there were only a few thousand, they immediately received significant representation in the party's bodies. On the contrary, in 1925 the communists look at Vrbenský as an unsuccessful politician, who had participated in the government in "anti-people's" measures and moreover had failed in the attempt to build his own

102 NA, f. 1017, k. 176, letter of Luisa Landová-Štychová to an unidentified leading representative of the KSČ, Vážený soudruhu (Dear Comrade), manuscript, 27. 9. 1925.

103 HOLUBEC, Stanislav: Lidé periferie. Sociální postavení a každodennost pražského dëlnictva $v$ meziválečné době (People on the Periphery. Social position and everyday life of the Prague working class in the interwar period). Západočeská univerzita v Plzni, Plzeň 2009, p. 207.

104 RUPNIK, Jacques: Dějiny komunistické strany Československa. Od počátkủ do převzetí moci (The History of the Communist Party of Czechoslovakia. From the beginnings to seizure of power). Academia, Praha 2002, p. 85.

105 Theodor Bartošek tried to unify the communist atheists to the much more significant Free Thought, which he chaired, and which then had 20,000 members. However, his joining of the KSČ aroused resistance in many of their members and in November 1925 he lost - albeit in a close race - the battle for the chairmanship. In February 1926, his fraction left the organisation (KUDLÁČ, Antonín: Př́běh(y) Volné myšlenky /Story(ies) of Free Thought/. NLN, Praha 2005, pp. 79-81) and in January of the next year joined the communist atheists (Ibid., p. 82).

106 Literární archiv Památníku národního písemnictví (Literary Archive of the Monument of National Literature), f. Majerová Marie (1038), 28/C/29, inv. No. 1521-1532, letter of Luisa Landová-Štychová to Marie Majerová, Milá Mařko (Dear Mařka), manuscript, 30. 10. 1925. 
party. Based on the poor results of the Independent Socialists in the 1923 municipal elections, it was clear to the Communist Party leaders that this party would expand their membership and electorate base only minimally. After all, the upcoming parliamentary elections proved them right: despite Vrbenskýs departure, the Socialist Party did not lose in them compared to the 1920 elections. Even in the North Bohemian region of Louny, where Vrbenský had the strongest support, he did not transfer many voters to the Communists from the Socialists. Compared to the last election, the second named fell from 51,000 to 43,000 votes ${ }^{107}$ and it is uncertain whether all their former voters supported the Communist Party at all. It was obvious that mainly the former Czech and German Social Democratic voters had joined the communists there.

\section{Conclusion}

What were the other destinies of the representatives of the Independent Socialists? In the early 1930s, Bohuslav Vrbenský turned his back on the Bolshevized Communist Party and was expelled from it. However, he returned to the party a few years later, was chairman of the Union of Friends of the USSR, and, after the municipal elections in May 1938, he became deputy mayor of Prague. After emigrating to the Soviet Union, he served as an officer in Czechoslovak military units and died in 1944 of a heart attack in Moscow. Vrbenský's closest collaborator, Vlastimil Borek, who worked as an editor of Rudé právo and a translator from Russian, remained in the communist movement throughout. During the war he was also in exile in Moscow and upon his return he worked at the Ministry of Foreign Affairs. He was a deputy Foreign Minister to Vladimir Clementis, and, shortly after his execution in 1952, he allegedly died of anxiety or perhaps committed suicide on the basis of false accusations of espionage. ${ }^{108}$ Luisa Landová-Štychová was a deputy for the KSČ for one term, but she no longer stood after its Bolshevization. In the 1930s, she engaged in anti-fascist groups, with luck survived the Nazi occupation, and after the war became an official of atheist and astronomical organizations. In the 1950s, she was a celebrated veteran of the movement, but she criticized many aspects of Czechoslovak Stalinism. Theodor Bartošek practiced law and remained active in non-believers' clubs. He survived a Nazi concentration camp and continued to promote not believing in God even after the war. The younger members of the movement made slightly larger careers in the Communist Party: Ivan Sekanina became the most famous communist lawyer in the 1930s, but was murdered in concentra-

107 Volby do zákonodárných orgánů Československa a České republiky, 1920-2006. K 90. výročí vzniku samostatného československého státu (Elections to the Legislative Bodies of Czechoslovakia and the Czech Republic, 1920-2006. On the $90^{\text {th }}$ anniversary of the creation of the independent Czechoslovak state). ČSÚ, Praha 2008, pp. 42, 48.

108 Vlastimil Borek (1886-1952) - see https://ahistorie.451.cz/borek-vlastimil-ing-1886-1952/ (quoted version dated 16. 12. 2021). 
tion camp. After 1945, Vladimír Matula was mayor of Brno and later ambassador to Denmark. Miloslav Matoušek became a professor at the Medical Faculty of Palacký University in Olomouc, he was significantly active politically and in 1968 he belonged to the pro-Soviet wing of the Communist Party. Other party representatives were no longer politically active and served as officials or editors (Jaroslav Štych, Miloslava Hrdličková-Šrámková, Zdena Soldanová).

It was Landová-Štychová, who after 1945 sought to ensure that a group of Independent Socialists did not fall into oblivion. In her memoirs, she overstated their importance, e.g., she exaggerated the numbers of voters and members that Vrbensky's group brought to the Communist Party. In one memoir she stated that there were 10,000 new members, ${ }^{109}$ elsewhere even that there were 27,000 miners from the north of Bohemia and 4,000 other members. ${ }^{110}$ At the same time, she remained silent that the Miners' Association did not join the Communist Party at all, but continued to operate as an independent, and in 1930 returned to the National Socialist unions. ${ }^{111}$ She also portrayed Independent Socialists as always completely pro-communist. We can hardly believe her claim that the whole matter with the Independent Socialist Party was from the beginning just a trick of its leaders to psychologically prepare Vrbensky's supporter for joining the Communist Party, consulted with the communist leader Bohumil Šmeral from the very beginning. ${ }^{112}$ Finally, she expressed embarrassment that Vrbenský was not entrusted with any position in the Communist Party and accused the then party leader Bohumil Jílek, who was later overthrown by Gottwald's faction and expelled. In 1945, she remembered it thus: Then precisely the knob Jilek of unfortunate memory. [...] Vrbenský was put on ice, he was not even accepted in the central executive committee and all at once became here as a political corpse, he, full of life and wonderful working energy. ${ }^{113}$ At the time of the political trials of the 1950s, Landová Štychová somewhat expanded the circle of culprits of Vrbenskýs isolation: Today, after the intrigue of the Slánsky group was revealed, the whole matter is understandable. [...] c[omrade] Dr. Vrbenský was not entrusted with any post in the party at the will of Jilek, [Václav] Bolen and probably also at the instigation of [Rudolf] Slánský.114

109 NA, f. 1017, k. 6, Luisa Landová-Štychová, Co u nás předcházelo vzniku Komunistické strany Československa (What went before the emergence of the Communist Party of Czechoslovakia here), manuscript, 13. 2. 1951, p. 10.

110 Ibid., k. 23, Luisa Landová-Štychová, document with a title: Luisa Landová-Štychová, typescript, undated, approximately 1948-1951, p. 7.

111 KOUKAL, Pavel: Václav Draxl, p. 47.

112 NA, f. 1017, k. 170, Luisa Landová-Štychová, document with a title starting with the words Viz proč čeští anarchokom. do strany čes. socialist (See why the Czech anarcho-communists to the Czechoslovak Socialist Party), manuscript, undated, approximately 1950s, p. 2.

113 Ibid., k. 129, dopis Luisy Landové-Štychové Marii Zápotocké (Letter of Luisa Landová-Štychová to Marie Zápotocká), Drahá a vážená soudružko Zápotocká (Dear and Revered Comrade Zápotocká), typescript, 30.11. 1945, p. 2.

114 Ibid., k. 2, Luisa Landová-Štychová, Smrt soudr. MUDr. Bohuslava Vrbenského v Moskvě dne 25. listopadu 1944 o 2 hod. v noci (The death of Comrade MUDr. Bohuslav Vrbenský in Moscow on 25. 11. 1944 at $2 \mathrm{AM}$ in the morning), manuscript, undated, after 1952. 
The attempt at an independent socialist party demonstrates how difficult it was to establish successful political entities in a relatively stabilized parliamentary system such as the First Republic. If new successful entities emerged, it was in response to ground-breaking international events (the Bolshevik revolution leading to the emergence of the KSČ, the rise of Adolf Hitler in Germany leading to the creation of the Sudetendeutsche Partei/SdP). All other attempts were unsuccessful on the right, centre and left. The new parties did not stand a chance against the existing colossi with tens or hundreds of thousands of members, who could afford to pay officials and the party press from membership fees. In addition, the split-off entities had to fear deprivation of parliamentary seats, as happened to the Independent Socialists. The weakness of the Vrbenský party was also that it was more of a middle-class project, most of its representatives were intellectuals, sometimes university-educated, often by profession editors or clerks, which made it difficult for them to address the working class.

The personality of its leader is also crucial for the success of a political entity. Vrbenský had a halo of a man imprisoned by the Austrian authorities and a doctor-philanthropist. Acting at the head of several ministries guaranteed him general knowledge in the public, he was a charismatic speaker of a powerful figure and voice. But he also had his weaknesses: he was too impulsive, his participation in the parliamentary brawl is proved, ${ }^{115}$ he apparently lacked diplomatic dexterity and bureaucratic diligence. He could not compete with the greatest talents of First Republic politics such as Prime Minister Antonín Švehla, Foreign Minister and later President Edvard Beneš, Communist Party founder Bohumil Šmeral or later Communist leader Klement Gottwald. However, due to the lack of sources, it is difficult to fully evaluate the talent of this politician, and we can try to do so only from a few testimonies of his surroundings and political opponents. It is significant that Jiři Tůma, the author of the Vrbenský's biography published before 1989, did not consider his personality and abilities. ${ }^{116}$ The portrait of Vrbenský from his pen sounds strangely lifeless to him, similar to the biographies of most of the personalities of the communist pantheon at the time. Although Vrbenskýs death in 1944 was premature, we can hardly imagine him in Stalinist Czechoslovakia. His political resume was too complicated for a career at the time.

In any case, the fate of the Vrbenský group represents an interesting and not very well-known chapter in the history of the First Czechoslovak Republic in terms of the fate of this party, its political programme, social grounding and not very warm reception in the ranks of the Communist Party. The voluntary joining of the Independent Socialists in the Communist Party is an event that has not been repeated

115 NA, f. 1017, k. 10, letter of the Central Committee of the Czechoslovak Socialist Party in Prague to Luisa Landová-Štychová, Vážená sestro, typescript, 21. 12. 1920, pp. 1-2.

116 TŮMA, Jiří: Bohuslav Vrbenský. 
in the party's seventy-year history. The second entity absorbed by the Communist Party was the Social Democrats only in 1948, but in this case it was a forced merger.

The story of Vrbenský's failed attempt to establish an Independent Socialist Party shows us several things. Anarchists were a permanently marginal current of Bohemian politics, and even their certain "mainstreamisation" during the First World War and in the first post-war years did not change much, and a successful political party could hardly penetrate from this current. In addition, the Czechoslovak political landscape was relatively stabilised, which made it difficult to create new entities, although they could rely on several nationally known personalities and several thousand activists. Furthermore, it is clear that the Independent Socialists, after realizing their failure, did not aim for social democracy, but for the Communist Party because their entire anarchist tradition led them to sympathize with the Bolshevik revolution. In the Communist Party, however, the people representing this current did not have much success, because they differed from the majority of the party's membership in their rather middle-class habitus, as former members of the Socialist Party they had "suspicious" biographies and did not gain much respect even because it was a group that had been unsuccessful in previous years and quite small compared to the membership of the Communist Party. The failure of the Czech Independent Socialists does not deviate from European trends, where even in other countries in the 1920s and 1930s political groups standing between social democracy and communists remained marginal, because the dilemma of "going with Moscow" or staying on the platform of parliamentary democracy did not allow any compromise. 


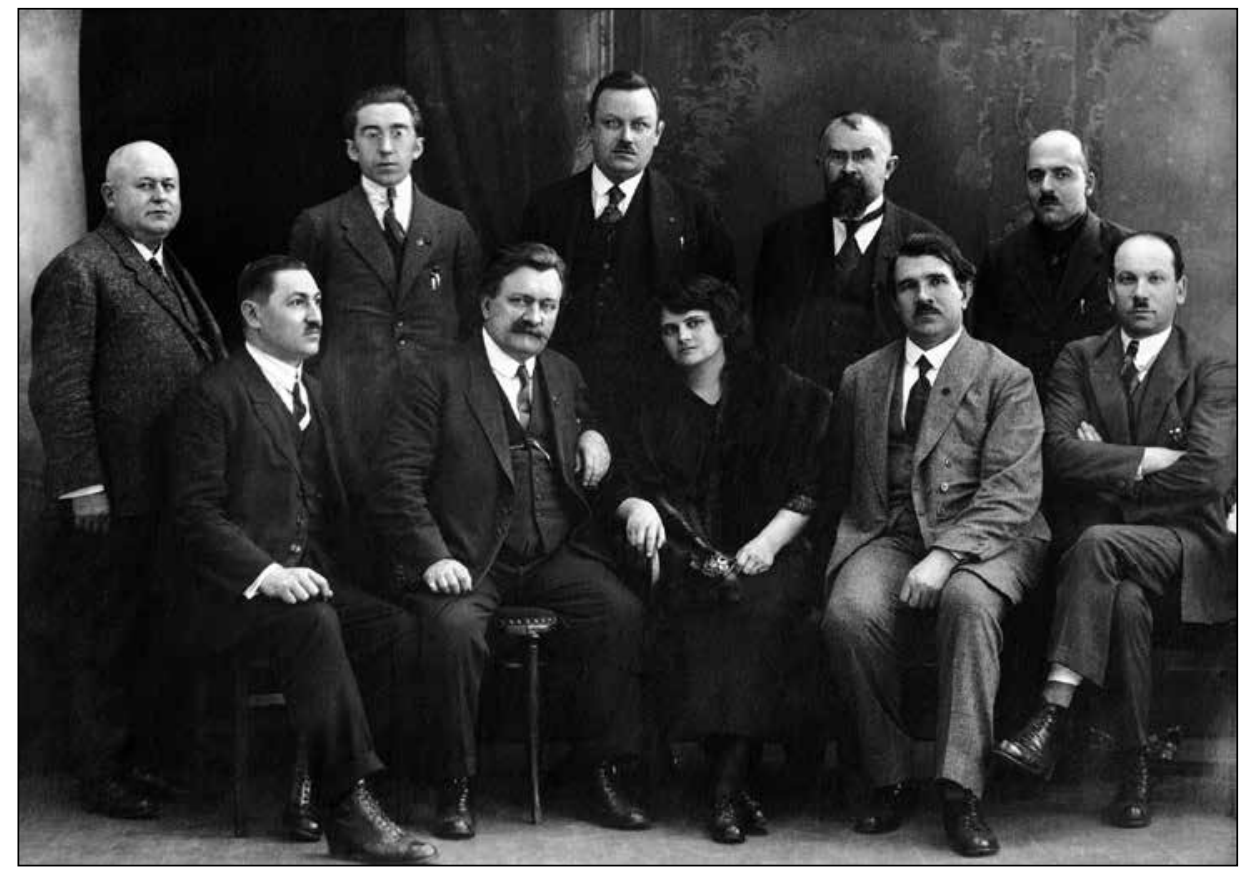

Presidency of the Socialist Unification, 1923, identifiable in the bottom row from the right: Robert Klein, Bohuslav Vrbensky, Luisa Landová-Štychová, Vilém Brodecký, in the top row second from the right Theodor Bartosek Source: NA, f. 1017, k. 130

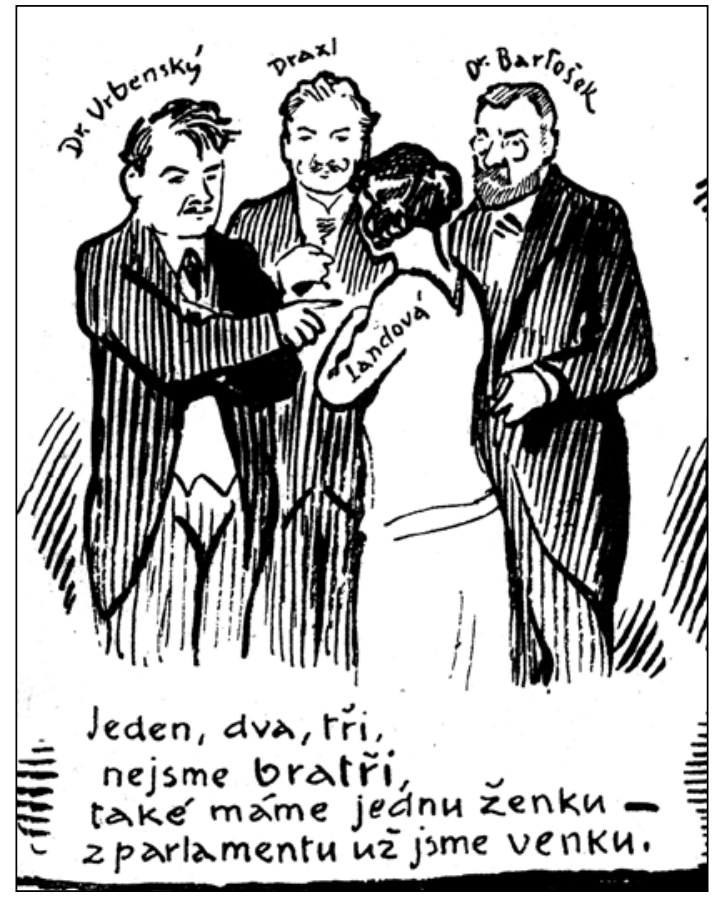

A caricature of MPs expelled from the Socialist Party 1923

Source: NA, f. 1017, k. 176 


\section{BIBLIOGRAPHY}

\section{Archival sources}

Národní archiv

f. Landová-Štychová Luisa (1017)

f. Archiv České strany národně sociální (1302)

f. Ministerstvo vnitra I - prezidium (225)

Archiv hlavního města Prahy

f. Magistrát hlavního města Prahy I. (zn. 4)

Státní okresní archiv Kladno

f. Landová-Štychová Luisa (1669)

Archiv Ministerstva zahraničních věcí

f. Osobní spisy II (54)

Literární archiv Památníku národního písemnictví,

f. Majerová Marie (1038)

\section{Secondary Literature}

15 kandidátních listin v Praze. Výsledky voleb. Národní listy, 3. 9. 1923, p. 1

FASORA, Lukáš: Stáří k poradě, mládí k boji. Radikalizace mladé generace českých socialistů 1900-1920. CDK, Brno 2015

FEINBERG, Melissa: Elusive Equality. Gender, Citizenship, and the Limits of Democracy in Czechoslovakia, 1918-1950. Pittsburgh University Press, Pittsburgh 2006 HAMŠÍK, Dušan: Louisa Landová-Štychová. Mladá fronta, 1. 2. 1950, p. 5 HOLUBEC, Stanislav: Lidé periferie. Sociální postavení a každodennost pražského de̋lnictva v meziválečné době. Západočeská univerzita v Plzni, Plzeň 2009

HOLUBEC, Stanislav: Neštastná revolucionářka. Myšlenkový svět a každodennost Luisy Landové-Štychové. NLN, Praha 2021

Kampaň proti dru Vrbenskému. Červen, 1919, Vol. 2, No. 13, p. 119

KÁRNÍK, Zdeněk: Socialisté na rozcestí. Habsburk, Masaryk či Šmeral? Svoboda, Praha 1968

KLÁTIL, František: Republika nad stranami. O vzniku a vývoji československé strany národně socialistické (1897-1948). Melantrich, Praha 1992

KLIMEK, Antonín: Boj o hrad 1. Hrad a pětka. Vnitropolitický vývoj Československa 1918-1926 na půdorysu zápasu o prezidentské nástupnictví. Tomáš Krsek, Buková u Př́ibrami 2017

KMONÍČEK, Josef: O životě Petra Pecha. Kruh, Hradec Králové 1978 
KOUKAL, Pavel: Václav Draxl. Masarykova demokratická akademie, Ústí nad Labem 2010

KŘESŤAN, Jiř́: Zdeněk Nejedlý a spolek socialistická společnost v Praze.

Paginae historiae, 2001, No. 9, pp. 222-268

KUDLÁČ, Antonín: Př́lběh(y) Volné myšlenky. NLN, Praha 2005

LANDOVÁ-ŠTYCHOVÁ, Luisa: První socialistický popularisátor astronomie ing. Jaroslav Štych. Nová skutečnost, 1952, Vol. 6, No. 1, p. 7

MALÁ, Jaroslava: Zákon na ochranu republiky (diplomová práce).

Právnická fakulta Univerzity Karlovy, Praha 2011

MAREK, Pavel: Český anarchismus. In: MALÍř́, Jiří - MAREK, Pavel a kol.: Politické strany. Vývoj politických stran a hnutí v českých zemích a Československu v letech 1861-2004, 1. díl (Období 1861-1938). Doplněk, Brno 2005, pp. 241-254

MAREK, Pavel: Čeští anarchokomunisté. In: MALÍŘ, Jiří - MAREK, Pavel a kol.: Politické strany. Vývoj politických stran a hnutív českých zemích a Československu v letech 1861-2004, 1. díl (Období 1861-1938). Doplněk, Brno 2005, pp. 747-762

Masky padly. České slovo, 7. 3. 1923, večerník, p. 1

Mimořádná valná hromada svazu. Plameny, 1913, Vol. 6, No. 7, not paginated MĚCHÝŘ, Jan: Bouřlivý kraj. Severočeské nakladatelství, Ústí nad Labem 1983 MĚCHÝŘ, Jan: Hornický sever s komunisty. Př́spěvek k založení KSČ $v$ severozápadních Čechách. Severočeské nakladatelství, Liberec 1961 OVČÁČKOVÁ, Lenka: Die Rezeption des naturwissenschaftlichen Monismus von Ernst Haeckel im tschechischen Kulturraum. In: MATIS, Herbert - REITER, Wolfgang L. (eds.): Darwin in Zentraleuropa. Die wissenschaftliche, weltanschauliche und populäre Rezeption im 19. und frühen 20. Jahrhundert. Lit Verlag, Wien 2018, pp. 311-341

PEROUTKA, Ferdinand: Budování státu, díl IV. Lidové noviny, Praha 1991

Politika. Nova doba, 8. 3. 1923, p. 3

Poslanecká sněmovna. Československá republika, 24. 3. 1923, s. 2

Povýšili jste moc nad právo, porušili jste ústavu - my si ji zase dobudeme. Vpřed. Župní orgán nezávislé Československé strany socialistické (Socialistické sjednocení), 5. 7. 1923, p. 1

Resignace dra Boh. Vrbenského. Národní listy, 6. 11. 1923, p. 3.

RUPNIK, Jacques: Dějiny komunistické strany Československa. Od počátků do prevezetí moci. Academia, Praha 2002

Řeč ministra br. Stř́ibrného před sborem důvěrníků čsl. strany socialistické v Plzni. Český směr. Deník Československé strany socialistické na českém západè, 16. 3. 1923, p. 1.

Sjezd českých anarchistů-komunistů. Červen, 1919, Vol. 2, No. 1, p. 9 Sjezd nezávislé socialistické strany dělnické v Československu. Socialista, 3. 11. 1923, p. 5 
Sjezd strany Socialistického sjednocení. Rudé právo, 1. 7. 1924, p. 1

Sjezd zbytečné strany. Nová doba, 2. 7. 1924, s. 3

SLAČÁLEK, Ondřej: Socialismus činu proti „vlažnému blátu“. Bývalí anarchisté, Svaz komunistických skupin a založení komunistické strany. Pamět a dějiny, 2021, Vol. 15, No. 2, pp. 20-33

Stoupencům českoslov. stany socialistické. Český směr. Deník Československé strany socialistické na českém západě, 8. 3. 1923, p. 1.

Výsledky v obcích, kde jsme se voleb zúčastnili a pokud jsou nám známy.

Socialista, 18. 9. 1923, pp. 1-2

ŠTVERÁK, František: Schematismus k dějinám komunistické strany Československa (1921-1992). Základní informace o ústředních orgánech a biografické údaje o vedoucích představitelích strany. NA ČR, Praha 2010

TOMEK, Václav: Český anarchismus 1890-1925. Filosofia, Praha 1996

TOMEK, Václav - SLAČÁLEK Ondřej: Anarchismus. Svoboda proti moci.

Vyšehrad, Praha 2006

TŮMA, Jiří: Bohuslav Vrbenský. O životě a díle revolucionáře. Severočeské nakladatelství, Ústí nad Labem 1980

VESELÝ, Pravoslav A.: Omladina a pokrokové hnutí. Trochu historie a trochu vzpomínek. Vlastním nákladem, Praha 1902

Volby do zákonodárných orgánů Československa a České republiky, 1920-2006. K 90. výročí vzniku samostatného československého státu. Čsú, Praha 2008 WOHLGEMUTHOVÁ, Renata: Příspěvek $k$ dějinám českého anarchistického hnutí $v$ letech 1900-1914. Academia, Praha 1971

ŽÁČKOVÁ, Zdeňka: Boj o paragraf 144. Potraty a legislativa za první republiky. Acta Historica Universitatis Silesianae Opaviensis, No. 9. Slezská univerzita v Opavě, Opava 2016, pp. 55-78

\section{Websites}

https://ahistorie.451.cz/borek-vlastimil-ing-1886-1952/

https://cs.wikisource.org/wiki/Z\%C3\%A1kon_na_ochranu_republiky 